\title{
Incidental detection of late presenting co-arctation of the aorta on chest x-ray: the importance of rib notching
}

\author{
Richard Roger Warne, ${ }^{1}$ Jeremy Sze Luong Ong, ${ }^{2}$ Conor P Murray ${ }^{1}$ \\ 1Department of Interventional and Diagnostic Radiology, Royal Perth Hospital, Perth, Western Australia, Australia; \\ 2Department of Geriatric Medicine, Royal Perth Hospital, Perth, Western Australia, Australia
}

Correspondence to Dr Richard Roger Warne, Richard.Warne@health.wa.gov.au

\section{Summary}

A 31 -year-old obese male presented to the emergency department with symptoms and signs suggestive of a viral upper respiratory tract illness with a background of low exercise tolerance. Rib notching was identified on plain film chest radiography and subsequent CT of the thorax identified a moderately tight 2-mm juxta-ductal co-arctation of the aorta with multiple enlarged chest wall collaterals. The patient underwent a two-stage percutaneous procedure involving stent insertion and angioplasty up to $16 \mathrm{~mm}$ with significant improvement in exercise capacity and a modest reduction in blood pressure.

\section{BACKGROUND}

Incidental detection of rib notching on plain film radiography led to a diagnosis of co-arctation of the aorta in a male patient. Subsequent endovascular intervention resulted in improvements in the patient's exercise capacity and energy levels and prevented the development of disastrous complications such as aortic dissection and cardiac failure.

Estimating the pretest probability of the presence of coarctation of the aorta is difficult when non-specific symptoms such as lack of energy and low exercise capacity are found on clinical assessment. Radio-femoral delay is the clinical sign classically associated with co-arctation of the aorta, but in the present case the trigger was rib notching found on chest radiography.

This case is important as co-arctation can be missed during postnatal screening or develop late. Clinicians and radiologists therefore need to be aware of rib notching.

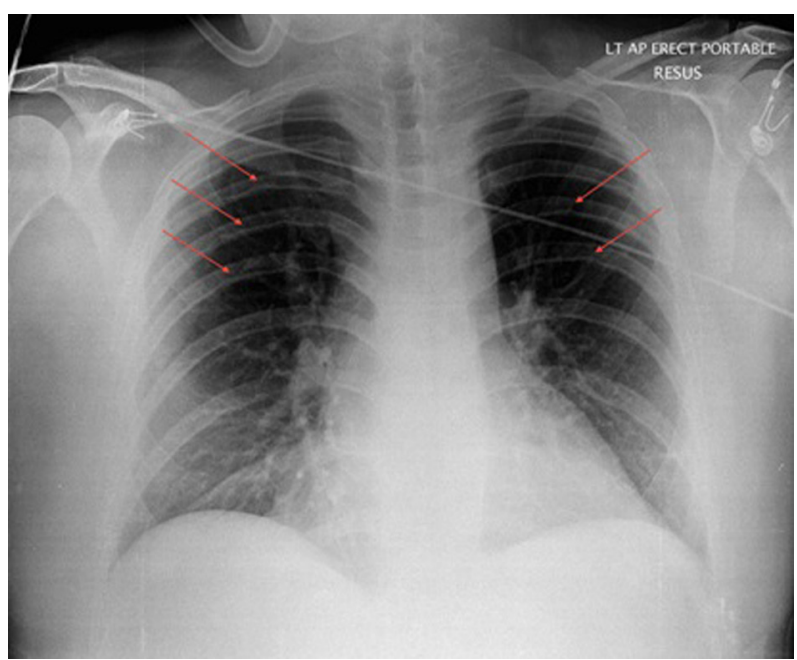

Figure 1 Plain film chest $x$-ray showing rib notching of the mid thoracic ribs bilaterally (arrows).

\section{CASE PRESENTATION}

A 31-year-old obese male presented to the emergency department with shortness of breath, productive cough, chest pain, nausea and vomiting over a 4-day period. The cough was productive of green sputum. The chest pain was sharp, worst posteriorly and brought on by coughing but not on deep inspiration. His breathlessness did not limit his daily functioning, although a subjective background of lifelong reduced exercise tolerance was noted. Significantly, three family contacts had symptoms of viral upper respiratory tract infection over 2 weeks prior to presentation. There was no recent travel history. There was a chronic history of reduced exercise tolerance, intermittent headaches, leg cramps on exertion and a childhood heart murmur, but none of these were considered significant enough to require further investigation. There was no history of

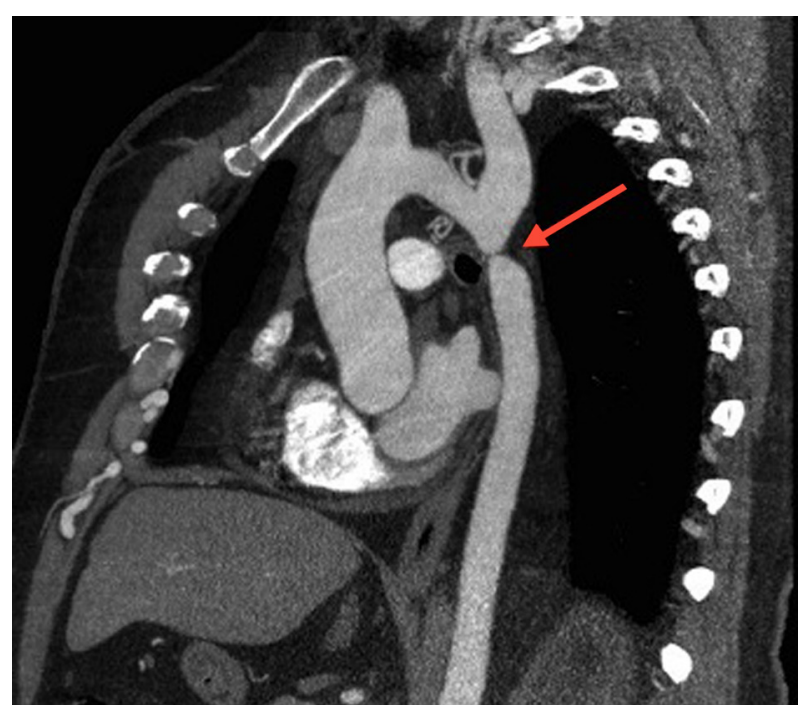

Figure 2 Preoperative cardiothoracic CT angiogram (sagittal oblique view) demonstrating co-arctation of the aorta (arrow). 
hypertension or diabetes. Family history was positive for ischaemic heart disease in his mother. He was on no regular medications. He was employed as an IT worker with a background in nursing, was married with three young children, was a non-smoker and consumed two to three standard drinks of alcohol per week.

On examination his blood pressure was 150/90 mm Hg, pulse was $90 \mathrm{bpm}$ with a regular rhythm, respiratory rate was $19 / \mathrm{min}$ and temperature was $36.9^{\circ} \mathrm{C}$. Cardiovascular examination revealed impalpable femoral pulses, a grade 1/6 systolic murmur and soft, non-tender calves. Respiratory examination revealed chest wall tenderness on palpation manoeuvres and right lower zone crepitations on auscultation.

These clinical features were most in keeping with an acute upper respiratory tract infection.

\section{INVESTIGATIONS}

Initial investigations included laboratory tests (cell counts and troponin), a 12-lead ECG and plain film chest radiography. Blood investigations were negative except for an elevated white cell count consistent with an acute infection. The 12-lead ECG revealed T-wave inversions in leads V4-V6, unchanged from a previous ECG.

The chest film revealed rib notching of the under surfaces of mid and upper-thoracic ribs (figure 1), a cardiothoracic ratio at the upper limit of normal and bilateral peribronchial cuffing in the lower zones consistent with bronchitis. The presence of borderline cardiomegaly and rib notching raised the possibility of aortic co-arctation or chronic anaemia.

Subsequent echocardiography did not confirm or exclude aortic co-arctation, but a thoracic CT scan revealed a focal postductal co-arctation of the aorta with mild dilatation of the proximal aorta and the left subclavian artery (figures 2 and 3). Multiple enlarged intercostals and chest wall collaterals were identified.

Cardiovascular MRI revealed an unrestricted bicuspid aortic valve and left aortic arch with normal branching pattern. There was enlargement of the right brachiocephalic trunk, left subclavian artery and internal mammary arteries with large intercostal vessels collateralising the distal aorta. Mild tubular hypoplasia of the aortic arch was also noted.

\section{DIFFERENTIAL DIAGNOSIS}

The differential diagnosis of rib notching includes vascular and non-vascular causes. Vascular causes are due to enlarged collateral intercostal vessels to the distal aorta, which subject adjacent ribs to greater pressure than usual, resulting in bony erosion. Implicated vessels can be arterial as in aortic co-arctation and Takayasu's arteritis, venous as in superior vena cava obstruction or arteriovenous as seen in arteriovenous fistulae. Non-vascular causes of rib notching include neurofibromatosis, intercostal neuromas and pseudo-rib notching where irregular cortical thickening may occur in the presence of tuberous sclerosis and hyperparathyroidism. Degrees of rib notching on chest radiography may also be of no clinical significance.

\section{TREATMENT, OUTCOME AND FOLLOW-UP}

Preprocedural imaging consisted of cardiovascular MRI, cardiac CT angiogram and transthoracic echocardiogram.

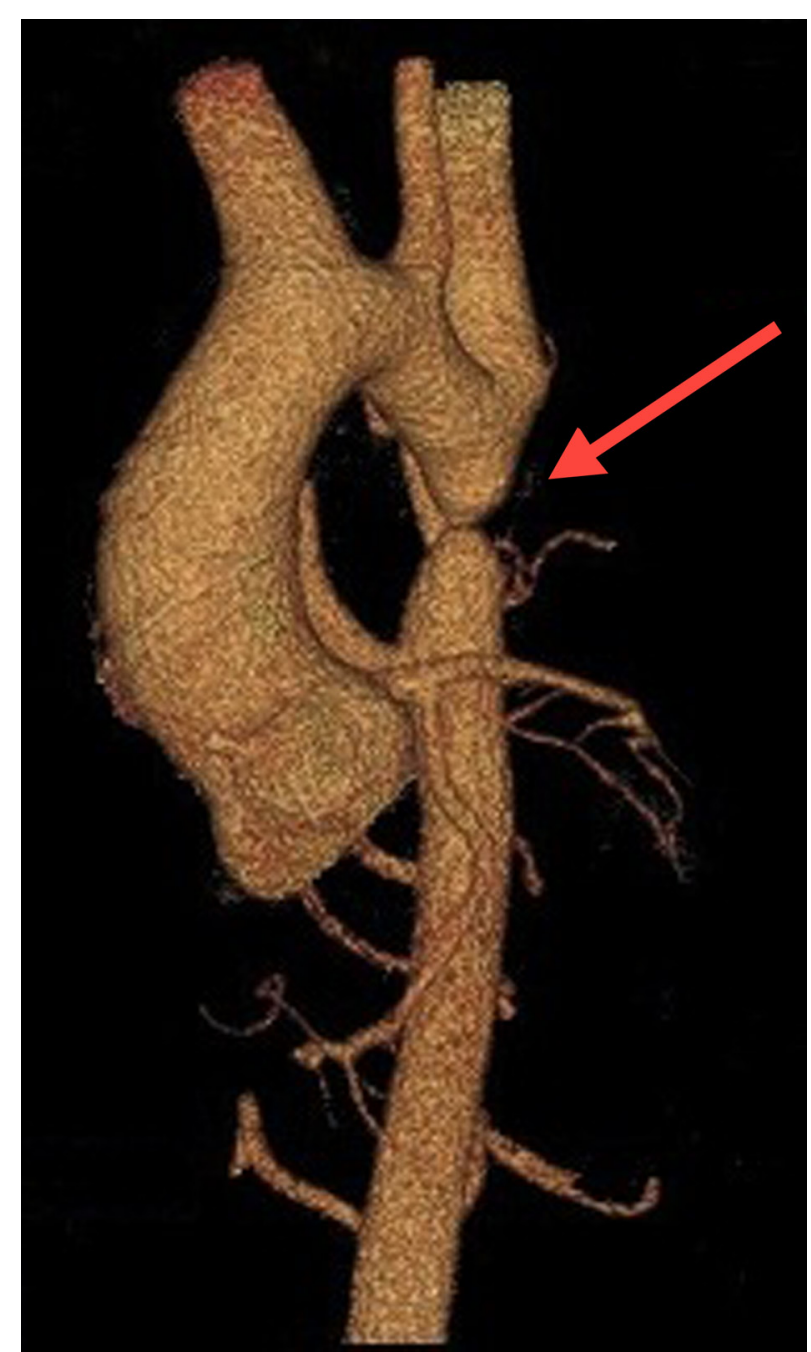

Figure 3 CT 3D reconstruction (anterior oblique view) demonstrating co-arctation of the aorta (arrow).

The patient underwent an uncomplicated endovascular aortic stent graft with left brachial artery and right femoral artery puncture with a $4 \times 4 \mathrm{~mm}$ balloon angioplasty following an intravenous heparin bolus of 5000 IU. A Cheatham stent was deployed up to $10 \mathrm{~mm}$ at the level of the co-arctation and $16 \mathrm{~mm}$ distal to the co-arctation site. Six months after this procedure the patient reported improvement in exercise tolerance without chest pain, palpitations or leg cramps. His blood pressure was $135 / 80 \mathrm{~mm} \mathrm{Hg}$, slightly reduced compared with initial presentation $(150 / 90 \mathrm{~mm}$ $\mathrm{Hg}$ ) and femoral pulses were palpable bilaterally. CT angiography of the aorta revealed a patent stent without evidence of displacement or narrowing.

Twelve months after the initial procedure the patient underwent an uncomplicated percutaneous transluminal angioplasty of the thoracic stent up to $18 \mathrm{~mm}$. Nine months after the angioplasty he reported further improvements in exercise capacity with no recurrence of chest pain or leg cramps. His blood pressure was 130/80 mm Hg. Echocardiography revealed normal left ventricular function with residual mild left ventricular hypertrophy. Follow-up management consisted of cardiovascular risk factor optimisation including caloric intake reduction to accompany increases in exercise as well as close monitoring of blood 


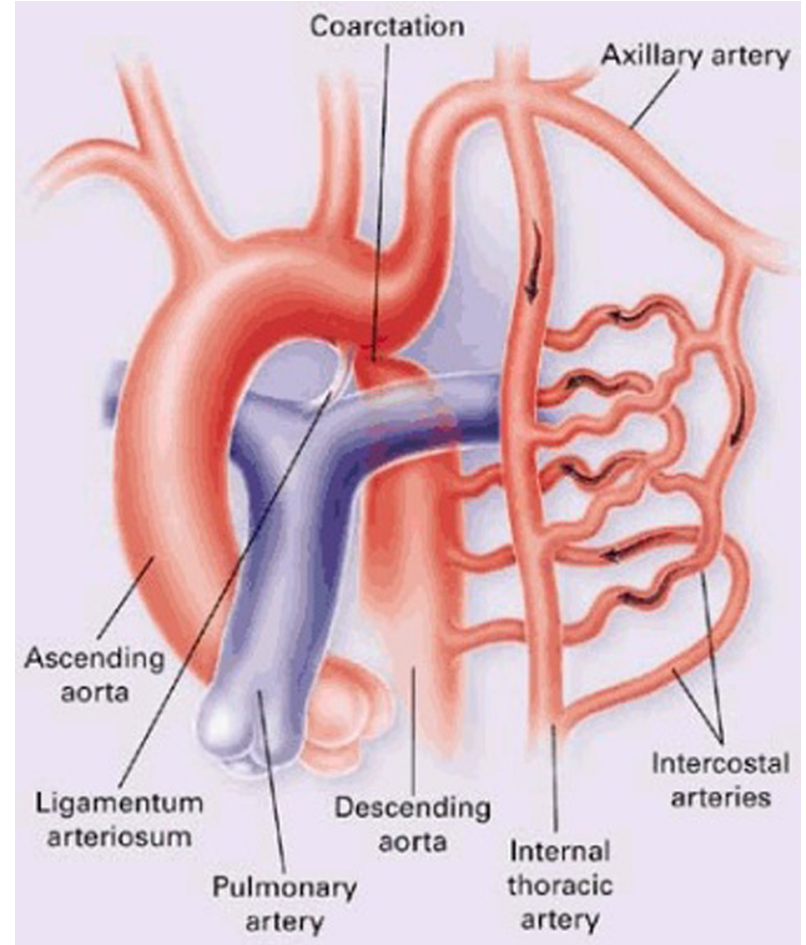

Figure 4 Schematic diagram showing the internal mammary artery and external thoracic artery collateralisation pathways and direction of flow. ${ }^{5}$ Image adapted from Brickner et al. ${ }^{5}$

pressure. The patient was well at the time of writing, 32 months after the angioplasty.

\section{DISCUSSION}

Co-arctation of the aorta is the sixth most common congenital heart condition in Australia, with 92 cases recorded in 2003 at a rate of 3.6 per 10000 live births. ${ }^{1}$ Diagnosis in adulthood is rare and has been associated with high mortality. Of those surviving past early childhood, historical data indicate $25 \%$ die before age $20,50 \%$ by age $32,75 \%$ by age 46 and $90 \%$ by 58 years. ${ }^{2}$ The most common cause of death was congestive heart failure, followed by aortic rupture, bacterial endocarditis and intracranial haemorrhage. ${ }^{2}$

Survival depends on the development of a collateral blood supply from the subclavian arteries (preco-arctation) to the aorta distal to the co-arctation via anastomoses with the intercostal arteries via three pathways: (1) the scapular pathway, including the transverse scapular and transverse cervical arteries originating from the thyrocervical trunk as well as the subscapular artery arising from the axillary artery; (2) the external thoracic pathway, including thoracic branches from the axillary artery; and (3) the internal mammary arteries ${ }^{3}$ (figure 4). Collateralisation is evidenced on chest $\mathrm{x}$-ray as rib notching, which has been long associated with co-arctation of the aorta. The first three and last two ribs are typically spared due to their blood supply arising from branches unaffected by the co-arctation. ${ }^{3-5}$

The sensitivity and specificity of rib notching for coarctation of the aorta have not been defined. The first parameters concerning the utility of rib notching come from a case series of 43 patients with co-arctation of the aorta diagnosed at autopsy aged 2 years or greater from $1946 .{ }^{6}$ Some $75 \%$ of these 43 subjects had recognisable rib notching, giving a false negative rate of $25 \%$. More recently, signs of a collateral circulation (rib notching and/ or a visible internal thoracic artery) were seen in $26 / 38$ patients with co-arctation of the aorta $(68 \%$, indicating a false negative rate of $32 \%)^{7}$ in one study, rib notching was seen in $39 / 61$ patients ( $64 \%$, false negative rate of $36 \%$ ) in another ${ }^{8}$ and there is also case report evidence of coarctation of the aorta without rib notching. ${ }^{9}$ These reports of false negative results of rib notching demonstrate limits to its sensitivity, but there are also reports that rib notching has limited specificity for co-arctation of the aorta despite a lack of numerical data. Rib notching has been visualised in the presence of other cardiovascular pathologies, ${ }^{3}$ nonvascular pathology ${ }^{4}$ and in up to $19 \%$ of healthy individuals ${ }^{10}$ (so-called pseudo rib notching).

There are also no reports on the sensitivity and/or specificity of radio-femoral delay, the classic examination sign associated with co-arctation of the aorta. Assessment for radio-femoral delay requires patients to uncover their groin area which may be a disincentive for clinicians in busy settings; additionally, locating femoral pulses can be difficult particularly in obese patients. ${ }^{11}$

An anecdotally reported alternative to radio-femoral delay involves comparing upper and lower limb systolic blood pressure, ${ }^{11}$ seeking a differential of at least $20 \mathrm{~mm}$ Hg. ${ }^{9}{ }^{12-16}$ Sensitivity and specificity for co-arctation of the aorta have not been calculated for this technique either, and its specificity is likely to be limited by the rarity of adult co-arctation of the aorta, especially with the comparatively high prevalence of peripheral arterial disease which can alter the ankle-brachial pressure index. ${ }^{17}$

Other signs which may aid the detection of co-arctation of the aorta include comparison of capillary refill times and temperature between the upper and lower limb extremities. ${ }^{18}$

Despite the uncertain relative utility of these techniques, it is important to be aware that each can be associated with co-arctation of the aorta and may warrant focused assessment and further investigation.

\section{Learning points}

- As co-arctation of the aorta can be missed during or develop after screening, clinicians and radiologists need to be aware of rib notching.

- Co-arctation of the aorta may present without hypertension and with non-specific symptoms of headache, low exercise capacity and intermittent leg cramps, which may not be considered significant enough for further investigation.

- Rib notching may be seen in co-arctation of the aorta due to enlarged collateral intercostal arteries and while not specific, mandates the consideration of co-arctation.

- Measurement of differences in lower limb and brachial arterial pressure is a reasonable and simple alternative to femoral pulse palpation but may be confounded by peripheral arterial disease.

- Capillary refill and temperature differences between the upper and lower limb extremities may also indicate co-arctation of the aorta. 


\section{BMJ Case Reports}

Acknowledgements Dr Jenny Ho (Central City Medical Centre, Perth, Western Australia) is thanked for her support.

\section{Competing interests None.}

Patient consent Obtained.

\section{REFERENCES}

1. Australian Institute of Health and Welfare 2011. In: Cardiovascular disease: Australian facts 2011. Cardiovascular disease series. Cat. no. CVD 53. Canberra: AlHW 2011.

2. Campbell M. Natural history of coarctation of the aorta. Br Heart J 1970;32:633-40.

3. Kagawa T, Nonoyama A, Kobayashi A. Rib notching: with reference to its various causes and diagnostic implications in cardiovascular diseases. Jpn Circ J 1968:32:989-94.

4. Cleland WP. Rib notching. Br Med J 1964;2:1152.

5. Brickner ME, Hillis LD, Lange RA. Congenital heart disease in adults. Second of two parts. N Engl J Med 2000;342:334-42.

6. Reifenstein GH, Levine SA, Gross RE. Coarctation of the aorta; a review of 104 autopsied cases of the adult type, 2 years of age or older. Am Heart $J$ 1947:33:146-68.

7. Huhmann W, Kunitsch G, Dalichau H. [Coarctation of the aorta on the plain chest x-ray (author's transI)]. Dtsch Med Wochenschr 1976;101:1477-81.
8. Wisheart JD. Coarctation of the aorta. Thorax 1970;25:347-54.

9. Varma C, McLaughlin PR, Hermiller JB, et al. Coarctation of the aorta in an adult: problems of diagnosis and management. Chest 2003;123:1749-52.

10. Boone ML, Swenson BE, Felson B. Rib notching: its many causes. Am J Roentgenol Radium Ther Nucl Med 1964;91:1075-88.

11. Beevers DG, Aitchison FA. Screening for aortic coarctation by comparing blood pressure in the arms and legs is more convenient and reliable than examination of the femoral pulses. J Hypertens 2011;29:1465-7.

12. Hsu LF, Sin Fai Lam KN, Rajasoorya C, et al. Hypertension in the young adult-come feel the pulse. Singapore Med J 2000;41:235-8.

13. Tsuang W, Ahmed K, Eckert D, et al. Case report: $\mathrm{CHD}$ as a potential cause of chest pain in adult patients. Am Fam Physician 2008;78:911-14.

14. Ijland MM, Tanke RB. Aortic coarctation. Circulation 2009;120:1294-5.

15. Muppidi S, Ngeny G, Onwuanyi A. Coarctation of aorta with normal blood pressure. J Natl Med Assoc 2011;103:173-5.

16. Shih A, Wilson TW. Check for delay to avoid delay. Perspectives in Cardiology 2007;23:24-6.

17. Resnick HE, Lindsay RS, McDermott MM, et al. Relationship of high and low ankle brachial index to all-cause and cardiovascular disease mortality: the Strong Heart Study. Circulation 2004;109:733-9.

18. Gerbode F. A simple test to identify coarctation of the aorta. Ann Surg 1976;184:615-7.

This pdf has been created automatically from the final edited text and images.

Copyright 2012 BMJ Publishing Group. All rights reserved. For permission to reuse any of this content visit http://group.bmj.com/group/rights-licensing/permissions.

BMJ Case Report Fellows may re-use this article for personal use and teaching without any further permission.

Please cite this article as follows (you will need to access the article online to obtain the date of publication).

Warne RR, Ong JSL, Murray CP. Incidental detection of late presenting co-arctation of the aorta on chest x-ray: the importance of rib notching. BMJ Case Reports 2012;10.1136/bcr.12.2011.5347, Published XXX

Become a Fellow of BMJ Case Reports today and you can:

- Submit as many cases as you like

- Enjoy fast sympathetic peer review and rapid publication of accepted articles

- Access all the published articles

- Re-use any of the published material for personal use and teaching without further permission

For information on Institutional Fellowships contact consortiasales@bmjgroup.com

Visit casereports.bmj.com for more articles like this and to become a Fellow 